\author{
RENATA BADOWIEC \\ Uniwersytet Mikołaja Kopernika w Toruniu \\ r.bad@onet.pl
}

\title{
Zakaz pracy w godzinach nadliczbowych
}

\section{A ban on working overtime}

Streszczenie. Praca wykonywana ponad ustalone normy czasu pracy wymaga zwiększonego wysiłku ze strony pracownika. Celem opracowania jest analiza ograniczeń i wyłączeń dopuszczalności zatrudniania pracowników w godzinach nadliczbowych. W artykule zostały przede wszystkim przedstawione bezwzględne oraz względne zakazy zatrudniania pracowników w godzinach nadliczbowych. Analizie poddano również pojęcie pracy w godzinach nadliczbowych. Opracowanie zostało wzbogacone o stanowisko doktryny oraz aktualne orzecznictwo, które dotyczy omawianego problemu.

Słowa kluczowe: pracownicy; godziny nadliczbowe; zakaz pracy; ograniczenia i wyłączenia zatrudnienia.

Abstract. Work done over a fixed working time standards require an increased effort on the part of the employee. The objective is the analysis of the limitations and exclusions of hiring of employees in overtime. The article mainly presented absolute and relative prohibitions of employment of employees in overtime. Also were analysed the concept of working overtime. The article has been enhanced with the current line of the doctrine and jurisprudence.

Keywords: employees; overtime; prohibition of work; limitations and exclusions of employment.

\section{Wprowadzenie}

Zgodnie $\mathrm{z}$ art. $100 \$ 2$ pkt 4 k.p. na pracowniku ciąży powinność dbałości o dobro pracodawcy ${ }^{1}$. Świadczenie pracy w godzinach nadliczbowych jest więc obowiązkiem pracownika. Praca w godzinach nadliczbowych jest jednak ograniczana lub wyłączana poprzez wprowadzenie: zakazów zatrudniania niektórych kategorii pracowników w godzinach nadliczbowych, ograniczenie dopuszczalności zatrudniania pracowników w godzinach nadliczbowych oraz określenie dopuszczalnej przeciętnej liczby godzin nadliczbowych w tygodniu, a także roczny limit godzin nadliczbowych dla pracowników.

Zakazy zatrudniania pracowników w godzinach nadliczbowych zostały podzielone na dwie grupy. Należy wyróżnić zakazy bezwzględne, które obowiązują bez wyjątków oraz

\footnotetext{
${ }^{1}$ Ustawa z dnia 26 czerwca 1974 r. Kodeks pracy (tekst jedn.: Dz. U. z 2014 r. poz. 1502).
} 
zakazy względne. Obowiązują one w ograniczonym zakresie, jedynie w sytuacji, gdy pracownik nie wyrazi zgody na świadczenie pracy w godzinach nadliczbowych ${ }^{2}$.

Celem niniejszego opracowania jest zaprezentowanie ograniczeń i wyłączeń dopuszczalności zatrudniania pracowników w godzinach nadliczbowych. W artykule zostaną przedstawione bezwzględne oraz względne zakazy zatrudniania pracowników w godzinach nadliczbowych.

\section{Pojęcie pracy wodzinach nadliczbowych}

Artykuł 151 §1 k.p. stanowi, iż pracą w godzinach nadliczbowych jest praca wykonywana ponad normy czasu pracy obowiązujące pracownika, a także wykonywana przez niego praca ponad przedłużony dobowy wymiar czasu pracy, który wynika z obowiązującego pracownika systemu i rozkładu czasu pracy. Dlatego też z pracą w godzinach nadliczbowych ma się do czynienia w przypadku, gdy zostanie przekroczona norma dobowa (tygodniowa) ustalona w układzie zbiorowym pracy, regulaminie pracy zgodnie z przepisami lub wynikająca wprost z przepisów ${ }^{3}$.

Ustawowa definicja akcentuje fakt „wykonywania pracy” oraz „przekroczenia obowiązujących norm bądź wymiaru czasu pracy”. Aby wyartykułować brakujące elementy przedmiotowej definicji pracy w godzinach nadliczbowych, należy sięgnąć do pojęcia „czasu pracy”, które związane jest z faktem pozostawania pracownika w dyspozycji pracodawcy, rozumianej jako obecność w zakładzie pracy albo w miejscu innym przeznaczonym do wykonywania pracy, w stanie psychofizycznym umożliwiającym jej podjęcie ${ }^{4}$.

Na uwagę zasługuje fakt, iż w praktyce orzeczniczej często dochodzi do mylenia pojęć „praca wykonywana” oraz „wykonywanie pracy”. W treści art. $151 \S 1$ k.p. ustawodawca użył pierwszego zwrotu, który należy rozumieć jako „praca świadczona”, „praca realizowana” lub „praca spełniana”. W orzecznictwie oraz doktrynie prezentowane jest stanowisko, że słowo „wykonywanie” wskazuje na aktywne zachowanie się pracownika, jego czynną postawę i działanie w realizacji zadań, które wynikają ze stosunku pracy. W związku z tym należy uznać, iż praca $\mathrm{w}$ godzinach nadliczbowych wykonywana jest wyłącznie w przypadku efektywnego świadczenia pracy przez pracownika, czyli rzeczywistego wykonywania ciążących na nim obowiązków. Funkcjonuje również pogląd przeciwny, zgodnie z którym czas, w którym pracownik pozostawał $\mathrm{w}$ dyspozycji pracodawcy poza podstawowymi godzinami pracy, ale faktycznie nie wykonywał pracy z przyczyn dotyczących pracodawcy,

\footnotetext{
${ }^{2}$ L. Florek, Prawo pracy, Warszawa 2012, s. 174.

${ }^{3}$ I. Jaroszewska - Ignatowska, Czas pracy po nowelizacji, Warszawa 2003, s. 84.

${ }^{4} \mathrm{P}$. Wąż, Polecenie pracy w godzinach nadliczbowych, http://www.pracaizdrowie.com.pl/content/view/480/3/ [dostęp: 2.08.2015 r.].
} 
powinien być uznany za pracę w godzinach nadliczbowych. Zdaniem B. Bury, na aprobatę zasługuje drugie stanowisko. Twierdzi ona, że ustawodawca, który posłużył się technicznym zwrotem ,praca wykonywana”, miał na celu wskazanie, kiedy praca powierzona jest wykonywana, a nie że jest ,wykonywana"

Na gruncie art. $151 \S 1$ k.p. pojawiły się także rozbieżności w zakresie interpretowania i stosowania owej definicji. Nastąpiło to w związku z zastosowaniem dwóch pojęć - „norma” oraz „wymiar”. W przypadku pojęcia pracy w godzinach nadliczbowych w odniesieniu do przekroczenia normy dobowej i średniotygodniowej poglądy w doktrynie pozostają zbieżne. Różnice pojawiają się przy pojęciu pracy w godzinach nadliczbowych w odniesieniu do przedłużonego dobowego wymiaru czasu pracy. Zwolennicy pierwszego poglądu wskazują, iż pojęcia „norma czasu pracy” i „wymiar czasu pracy” używane są zamiennie w przepisach działu szóstego kodeksu pracy. Wyróżniają oni normę czasu pracy lub wymiar czasu pracy w sensie ogólnym, a także zindywidualizowanym. W art. 151 §1 k.p. w przypadku przekroczenia obowiązujących pracownika norm czasu pracy mowa jest o wymiarze czasu pracy w znaczeniu zindywidualizowanym. Przedstawiciele tego poglądu wskazują również, że uznanie pracy przekraczającej 8 godzin na dobę za pracę w godzinach nadliczbowych nie znajduje uzasadnienia normatywnego, ponieważ przepis o tej treści (art. 129 §2 k.p.) został uchylony. Zwolennicy drugiego poglądu twierdzą, że pojęcia „norma czasu pracy” i „wymiar czasu pracy” nie są ze sobą tożsame. Według nich przekroczenie ogólnej normy czasu pracy skutkuje pracą w godzinach nadliczbowych. Dotyczy to także tych systemów czasu pracy, w których rozkład czasu pracy zakłada wydłużony wymiar czasu pracy ponad normę jednego dnia, natomiast innego dnia zostaje skrócony. Drugi pogląd znajduje swoje poparcie zarówno w stanowisku zajmowanym przez Ministerstwo Rodziny, Pracy i Polityki Społecznej, jak i przez Państwową Inspekcję Pracy ${ }^{6}$. Potwierdził go również wyrok Sądu Najwyższego z 10 marca 2005 r. Zostało w nim wskazane, że w systemie równoważnego czasu pracy za pracę $\mathrm{w}$ godzinach nadliczbowych uważana jest praca ponad normę dobową, która wynika $\mathrm{z}$ harmonogramu pracy, a także praca $\mathrm{w}$ czasie przekraczającym przeciętną normę tygodniową ${ }^{7}$.

\footnotetext{
${ }^{5}$ B. Bury, Praca w godzinach nadliczbowych, Warszawa 2007, s. 10-12.

${ }^{6}$ E. Wronikowska, Wynagrodzenie za prace w godzinach nadliczbowych, Warszawa 2007, s. 16-20.

${ }^{7}$ Wyrok Sądu Najwyższego z dnia 10 marca 2005 r., II PK 241/04, OSNP, nr 24, poz. 393.
} 


\section{Przesłanki dopuszczalności pracy w godzinach nadliczbowych}

Praca w godzinach nadliczbowych dopuszczalna jest tylko w sytuacjach ściśle określonych przepisami kodeksu pracy z tego względu, iż wydłuża ona czas pracy pracownika ponad obowiązujące normy ${ }^{8}$. Przepis art. $151 \S 1$ k.p. dopuszcza pracę w godzinach nadliczbowych tylko w dwóch przypadkach:

- w razie konieczności prowadzenia akcji ratowniczej w celu ochrony życia lub zdrowia ludzkiego, ochrony mienia lub środowiska albo usunięcia awarii;

- gdy wynika to ze szczególnych potrzeb pracodawcy.

Przepisy te mają charakter ius cogens. Oznacza to, iż nie jest prawnie dopuszczalne ustanawianie nieznanych kodeksowi przyczyn pracy w godzinach nadliczbowych w regulaminach pracy, układach zbiorowych, statutach lub w umowie o pracę 9 .

W przypadku pierwszej z przesłanek konieczność pracy w godzinach nadliczbowych wynika z nagłych i nieprzewidzianych zdarzeń, które powodują potrzebę zorganizowania akcji ratowniczej lub usunięcia skutków awarii. Działania, które zostają podjęte, mają na celu ochronę życia, zdrowia ludzkiego, środowiska naturalnego lub mienia zakładu pracy. Do takich sytuacji należą: pożary, huragany, trzęsienia ziemi, awarie maszyn i urządzeń w zakładzie pracy, katastrofy (budowlane, drogowe, morskie, lotnicze). Kiedy występuje konieczność przeprowadzenia akcji ratowniczej lub usunięcia awarii innego rodzaju, pracownikowi można zlecić pracę inną niż wynika to z umowy o pracę. Gdy zachodzi potrzeba przeprowadzenia akcji ratowniczej, pracownik nie może odmówić podjęcia pracy w godzinach nadliczbowych ${ }^{10}$. W jednym z orzeczeń Sądu Najwyższego zostało wskazane, iż praca w godzinach nadliczbowych wykonywana jest w warunkach określonego już zmęczenia pracownika. Nie znajduje jednak uzasadnienia odmowa pracownika wykonania polecenia pozostania poza godzinami pracy, aby zakończyć usuwanie awarii, nawet w przypadku, gdy pracownik uważa, że został niesłusznie pozbawiony premii, bowiem może jej dochodzić na drodze prawnej ${ }^{11}$. W przypadku konieczności prowadzenia akcji ratowniczej w celu ochrony życia lub zdrowia ludzkiego, ochrony mienia lub środowiska albo usunięcia awarii liczba przepracowanych nadgodzin nie jest limitowana. Jeśli więc pracownik otrzyma polecenie

\footnotetext{
${ }^{8}$ M. Nałęcz, w: Kodeks pracy. Komentarz, red. W. Muszalski, Warszawa 2005, s. 505.

${ }^{9}$ A. Chobot, Czas pracy w znowelizowanym kodeksie pracy, Poznań 1998, s. 211-212.

${ }^{10}$ E. Wronikowska, Wynagrodzenie..., s. 39-40.

${ }^{11}$ Wyrok Sądu Najwyższego z dnia 16 grudnia 1987 r., I PRN 68/87, OSNCP, z. 10, poz. 164.
} 
pracy nadliczbowej z tej przyczyny, to nie będą obowiązywały go żadne limity godzin nadliczbowych - zobowiązany będzie pracować przez taki czas, jaki został mu zlecony ${ }^{12}$.

Pojęcie „szczególnych potrzeb pracodawcy” jest określeniem ogólnym, a w literaturze wskazuje się, iż jest ono przeciwstawne od normalnych i zwykłych potrzeb pracodawcy, w związku z prowadzoną przez niego działalnością. Ocena w kwestii szczególnych potrzeb należy do pracodawcy, jednak nie ma on $\mathrm{w}$ tym względzie pełnej dowolności. Praca w godzinach nadliczbowych nie może służyć wykonywaniu planowych zadan ${ }^{13}$. W tym przypadku chodzi o specjalne, wyjątkowe i niecodzienne potrzeby. „Szczególne potrzeby” mają charakter niecodzienny, a więc z reguły powinny być również krótkotrwałe. Kwestią problematyczną jest ustalenie, czy w przypadku zlecenia pracy w godzinach nadliczbowych ze względu na „szczególne potrzeby” pracodawca związany jest rodzajem pracy określonym w umowie o pracę, czy też może wydać pracownikowi polecenie wykonania czynności każdego rodzaju. W tym względzie ukształtowały się dwa przeciwstawne poglądy. Pierwszy $\mathrm{z}$ nich prezentowany jest $\mathrm{w}$ orzecznictwie sądowym. Zgodnie $\mathrm{z}$ nim zlecenie pracy w godzinach nadliczbowych wiąże pracownika nie tylko wówczas, gdy zlecono mu pracę zgodną z umówionym rodzajem, ale także wtedy, gdy zlecona praca jest innego rodzaju. Zwolennicy drugiego stanowiska wskazują, że kiedy zachodzą „szczególne potrzeby” pracownik zobowiązany jest do świadczenia pracy w godzinach nadliczbowych wyłącznie w zakresie umówionego rodzaju pracy. Według B. Bury na aprobatę zasługuje drugi z zaprezentowanych poglądów, a przemawia za tym m.in. argument, że obowiązek wykonania w ramach stosunku pracy czynności innych niż umówione powstaje tylko wyjątkowo i podlega reglamentacji. Intencją ustawodawcy było natomiast ograniczenie przypadków wykonywania pracy przekraczającej ustalone normy czasu pracy jedynie do tych sytuacji, w których obecność pracownika oraz świadczona przez niego praca niezbędne są z punktu widzenia pracodawcy, a nieobecność pracownika spowodowałaby zakłócenie procesu pracy ${ }^{14}$.

Odmowa przez pracownika pracy $\mathrm{w}$ godzinach nadliczbowych może stanowić przesłankę naruszenie ciążącego na nim obowiązku, a ponadto może być podstawą do rozwiązania umowy o pracę bez wypowiedzenia $\mathrm{z}$ winy pracownika lub ukarania pracownika karą porządkową. Pracownik nie może więc odmówić pracy w godzinach nadliczbowych.

\footnotetext{
${ }^{12}$ I. Jaroszewska - Ignatowska, Czas pracy..., s. 87.

${ }^{13}$ E. Wronikowska, Wynagrodzenie..., s. 41.

${ }^{14}$ B. Bury, Praca..., s. 66-69.
} 
Wyjątkiem jest sytuacja, gdy polecenie pracodawcy jest sprzeczne z prawem ${ }^{15}$. W związku z tym pracownik będzie miał możliwość odmowy pracy w godzinach nadliczbowych, gdy polecenie takie będzie bezprawne, a ponadto kiedy okaże się sprzeczne $\mathrm{z}$ zasadami współżycia społecznego ${ }^{16}$.

Do pracy w godzinach nadliczbowych należy nie tylko ta, która została wykonana z inicjatywy pracownika wyłącznie za zgodą i wiedzą pracodawcy, ale również ta, której konieczność wynika z obiektywnych przesłanek, w przypadku, gdy ilość powierzonych zadań nie może być wykonywana w ustawowych normach czasu pracy ${ }^{17}$. Sąd Najwyższy w wyroku z 26 maja 2000 r. wskazuje, iż warunkiem przyjęcia dorozumianej zgody pracodawcy na pracę $w$ godzinach na nadliczbowych jest świadomość pracodawcy, że pracownik taką pracę wykonuje ${ }^{18}$.

\section{Bezwzględne zakazy zatrudniania wodzinach nadliczbowych}

\subsection{Uwagi ogólne}

Zgodnie z treścią art. $178 \S 1$ k.p. bezwzględny zakaz pracy w godzinach nadliczbowych obejmuje pracownice w ciąży. Taki sam zakaz dotyczy pracowników młodocianych, o czym stanowi art. $203 \S 1$ k.p. W art. 15 ust. 3 ustawy o rehabilitacji zawodowej i społecznej oraz zatrudnianiu osób niepełnosprawnych zakazem zatrudniania $\mathrm{w}$ godzinach nadliczbowych zostali objęci pracownicy niepełnosprawni ${ }^{19}$. Bezwzględny zakaz pracy w godzinach nadliczbowych stosuje się $\mathrm{w}$ stosunku do pracowników zatrudnionych na stanowiskach, na których występują przekroczenia najwyższych dopuszczalnych stężeń i natężeń czynników szkodliwych dla zdrowia, nie ma jednak zastosowania art. $151 \S 1$ pkt 2 k.p. Ponadto z treści art. $207 \S 2$ k.p. można wyprowadzić zakaz zatrudniania w godzinach nadliczbowych osób, które przedstawią pracodawcy zaświadczenie zakładu opieki o niemożności wykonywania takiej $\operatorname{pracy}^{20}$.

\footnotetext{
${ }^{15}$ Tamże, s. 42-43.

16 M. Nałęcz, Kodeks..., s. 509.

${ }^{17}$ B. Bury, Praca ..., s. 46.

${ }^{18}$ Wyrok Sądu Najwyższego z dnia 26 maja 2000 r., I PKN 667/99, OSN 2001, nr 22, poz. 662.

19 Ustawa z dnia 27 sierpnia 1997 r. o rehabilitacji zawodowej i społecznej oraz zatrudnianiu osób niepełnosprawnych (tekst jedn.: Dz. U. z 2015 r. poz. 218).

${ }^{20}$ B. Bury, Praca ..., s. 89.
} 


\subsection{Kobiety w ciąży}

Ustawodawca stara się zapewnić ochronę kobiet w ciąży poprzez wprowadzenie bezwzględnego zakazu pracy $\mathrm{w}$ godzinach nadliczbowych. W tym przypadku chodzi o zapewnienie wzmożonej ochrony zdrowia i życia przyszłej matki, a także ustalanie odpowiedniego czasu wypoczynku zarówno dobowego, jak i tygodniowego. Z uwagi na fakt, iż praca w godzinach nadliczbowych wykonywana jest najczęściej w fazie dużego zmęczenia pracownika, taka praca mogłaby stanowić zagrożenie dla zdrowia, czy życia matki lub dziecka. Z tego względu ustawodawca zdecydował się na pierwszeństwo ochrony macierzyństwa, a nie interesu pracodawcy. Zakazem owej pracy objęte są wszystkie kobiety, bez względu na stan zaawansowania ciąży. $Z$ art. 178 §1 k.p. związany jest art. 148 pkt 2 k.p., który nakazuje, aby wymiar czasu pracy w systemach i rozkładach dopuszczających jego przedłużenie nie przekraczał w odniesieniu do pracownic w ciąży 8 godzin na dobę. Świadczy to niewątpliwie o wysokim poziomie ochrony pracownic w ciąży. Artykuł $185 \S 1$ k.p. stanowi, iż stan ciąży musi być stwierdzony świadectwem lekarskim. Dlatego też pracownica w ciąży podlega ustawowo przewidzianej ochronie dopiero od momentu przedstawienia pracodawcy owego zaświadczenia. Stanowi ono faktyczne potwierdzenie stanu ciąży ${ }^{21}$. Artykuł 178 §1 k.p. ma charakter bezwzględnie obowiązujący i dotyczy pracownicy w całym okresie ciąży. Oznacza to, że pracownica, nawet jeśli wyrazi zgodę, nie może być dopuszczona przez pracodawcę do świadczenia pracy w godzinach nadliczbowych ${ }^{22}$.

\subsection{Młodociani}

Zgodnie z art. 7 ust. 3 i 4 Europejskiej Karty Społecznej Strony Karty w celu zapewnienia skutecznego wykonywania prawa dzieci i młodocianych do ochrony, zobowiązały się do wprowadzenia zakazu, by dzieci, które podlegają jeszcze obowiązkowemu nauczaniu, były zatrudniane przy pracach, które uniemożliwiałyby im pełne korzystanie $\mathrm{z}$ tego nauczania oraz ograniczenia czasu pracy pracowników mających mniej niż 16 lat tak, aby odpowiadał potrzebom ich rozwoju, w szczególności potrzebie ich szkolenia zawodowego ${ }^{23}$. Artykuł $203 \S 1$ k.p., podobnie jak pozostałe przepisy działu dziewiątego kodeksu pracy, mają na celu zapewnienie ochrony przede wszystkim zdrowia, ale również warunków prawidłowego rozwoju fizycznego i umysłowego młodych pracowników. Ustawodawca poprzez

\footnotetext{
${ }^{21}$ Tamże, s. 91-92.

${ }^{22}$ M. Nałęcz, w: Kodeks..., s. 637.

${ }^{23}$ Europejska Karta Społeczna z dnia 18 października 1961 r. (tekst jedn.: Dz.U. z 1999 r. poz. 67).
} 
wprowadzenie zakazu pracy $\mathrm{w}$ godzinach nadliczbowych tej grupy pracowników chce chronić słabszy organizm osoby młodocianej przed przeciążeniem, które mogłoby powstać w wyniku takiej pracy. Rozwiązanie to uwzględnia także konieczność kształcenia się młodocianego oraz możliwość realizacji wobec niego obowiązku szkolnego, który w ustawodawstwie polskim ma rangę konstytucyjną ${ }^{24}$. Zakaz pracy $w$ godzinach nadliczbowych obejmuje wszystkie osoby młodociane, bez względu na podstawę zatrudnienia (umowa o pracę w celu przygotowania zawodowego lub „zwykła” umowa o pracę). Treść art. $203 \S 1$ k.p. związana jest z art. 203 §3 k.p., który stanowi, że młodocianemu przysługuje w każdym tygodniu prawo do co najmniej 48 godzin nieprzerwanego odpoczynku, który powinien obejmować niedzielę. Przemawia za tym ochrona zdrowia pracowników niepełnoletnich w związku z regeneracją ich $\operatorname{sil}^{25}$. Dla osób, które nie ukończyły 16. roku życia, a których zatrudnienie możliwe jest w przypadkach określonych w rozporządzeniu Ministra Pracy i Polityki Społecznej wydanym w porozumieniu z Ministrem Edukacji Narodowej, norma dobowa, po której zaczyna się praca w godzinach nadliczbowych młodocianych wynosi 6 godzin (zgodnie z art. 191 §5 k.p.), natomiast w stosunku do młodocianych powyżej 16 lat norma ta wynosi 8 godzin (na podstawie art. $202 \S 1$ i 2 k.p.). Z zakazu pracy $\mathrm{w}$ godzinach nadliczbowych osób młodocianych wynika zakaz pracy w niedziele i święta, jeśli zatrudnienie podczas takich dni spowodowałoby przekroczenie normy czasu pracy młodocianego, a nie zostałoby to zrekompensowane poprzez udzielenie dnia wolnego. Na podstawie art. 281 pkt 5 k.p. sankcją za naruszenie przepisów o czasie pracy lub przepisów o uprawnieniach pracowników związanych $\mathrm{z}$ rodzicielstwem i zatrudnianiu młodocianych jest odpowiedzialność wykroczeniowa pracodawcy. $\mathrm{Na}$ pracodawcy ciąży ponadto obowiązek zapłacenia wynagrodzenia wraz z dodatkiem za pracę świadczoną w godzinach nadliczbowych wbrew zakazowi ${ }^{26}$.

\subsection{Niepelnosprawni}

Ustawa o rehabilitacji zawodowej i społecznej oraz zatrudnianiu osób niepełnosprawnych dotyczy osób, których niepełnosprawność została potwierdzona orzeczeniem o zakwalifikowaniu przez organy orzekające do jednego z trzech stopni niepełnosprawności (znaczny, umiarkowany, lekki), o całkowitej lub częściowej niezdolności do pracy na podstawie odrębnych przepisów lub o niepełnosprawności wydanym przed ukończeniem

\footnotetext{
${ }^{24}$ B. Bury, Praca..., s. 93-94.

${ }^{25}$ M. Nałęcz, Kodeks..., s. 684.

${ }^{26}$ B. Bury, Praca ..., s. 93-94.
} 
16 roku życia ${ }^{27}$. Artykuł 15 ust. 3 ustawy stanowi, iż osoba niepełnosprawna nie może być zatrudniona $\mathrm{w}$ porze nocnej $\mathrm{i}$ w godzinach nadliczbowych. Zakaz pracy $\mathrm{w}$ godzinach nadliczbowych odnosi się do wszystkich dopuszczalnych przypadków stosowania tej pracy, które zostały wskazane w art. $151 \S 1$ k.p. Dla tej grupy pracowników pracę w godzinach nadliczbowych będzie stanowiła ta, która przekroczy 8 godzin na dobę lub 40 godzin tygodniowo, a w przypadku osób niepełnosprawnych zaliczonych do znacznego lub umiarkowanego stopnia niepełnosprawności - 7 godzin na dobę i 35 godzin tygodniowo. Skrócone normy czasu pracy stosowane są do pracownika niepełnosprawnego od dnia następującego po dniu przedstawienia orzeczenia o niepełnosprawności ${ }^{28}$. Zgodnie $\mathrm{z}$ treścią art. 16 ustawy zakazu tego nie stosuje się do osób zatrudnionych przy pilnowaniu oraz gdy na wniosek osoby zatrudnionej, lekarz przeprowadzający badania profilaktyczne pracowników lub w razie jego braku lekarz sprawujący opiekę nad tą osobą wyrazi na to zgodę. W tych dwóch przypadkach istnieje możliwość zatrudnienia osób niepełnosprawnych w godzinach nadliczbowych, jednak należy uwzględnić przepisy zawarte w kodeksie pracy ${ }^{29}$. Wyłączenia te obejmują wszystkich pracowników niepełnosprawnych, bez względu na stopień ich niepełnosprawności. Pracownicy zatrudnieni przy pilnowaniu objęci są normą czasu, która obowiązuje u zatrudniającego ich pracodawcy, czyli taką samą jak inni pracownicy zatrudnieni przy pilnowaniu. Mogą oni być zatrudniani w godzinach nadliczbowych. W takim przypadku obowiązują przepisy zawarte w kodeksie ${ }^{30}$.

\subsection{Pracownicy zatrudnieni na stanowiskach, na których występują przekroczenia najwyższych stężeń lub natężeń czynników szkodliwych dla zdrowia}

Zgodnie z treścią art. 151 §2 k.p. nie można zlecać pracy w godzinach nadliczbowych pracownikom zatrudnionym na stanowiskach pracy, na których występują przekroczenia najwyższych dopuszczalnych stężeń lub natężeń czynników szkodliwych dla zdrowia. Zakaz ten dotyczy jedynie pracy $\mathrm{w}$ godzinach nadliczbowych potrzebnej dla zabezpieczenia szczególnych potrzeb pracodawcy. W sytuacji konieczności podjęcia akcji ratowniczej pracownicy mają obowiązek powzięcia wszelkich działań również po upływie normalnego czasu pracy ${ }^{31}$. W przypadku świadczenia pracy w warunkach przekroczenia najwyższych

\footnotetext{
${ }^{27}$ Zob. art. 1 ustawy o rehabilitacji zawodowej i społecznej oraz zatrudnianiu osób niepełnosprawnych.

${ }^{28}$ B. Bury, Praca..., s. 94.

${ }^{29}$ A. Thiel, Czas pracy osób niepetnosprawnych, w: Zatrudnianie osób niepetnosprawnych. Regulacje prawne, red. A. Giedrewicz - Niewińska, M. Szabłowska - Juckiewicz, Warszawa 2014, s. 247.

${ }^{30}$ B. Bury, Praca ..., s. 94.

${ }^{31}$ E. Wronikowska, Wynagrodzenie..., s. 49.
} 
dopuszczalnych stężeń albo natężeń czynników szkodliwych dla zdrowia narażenie zawodowe rośnie proporcjonalnie do czasu oddziaływania tych czynników na pracownika. Najwyższa wartość, która jest dopuszczalna przy stężeniach lub natężeniach czynników szkodliwych dla zdrowia w miejscu pracy porównywalna jest do norm: dobowej i tygodniowej, odpowiadających podstawowemu wymiarowi czasu pracy. Należy więc wnioskować, że zakaz zatrudniania pracownika w godzinach nadliczbowych $\mathrm{w}$ tym przypadku dotyczy pracy w wymiarze ponad 8 godzin na dobę i powyżej 40 godzin na tydzień (przy przeciętnym pięciodniowym tygodniu pracy). W literaturze można spotkać pogląd, że możliwość polecenia pracy w godzinach nadliczbowych odnosi się jedynie do przypadków prowadzenia akcji ratowniczej dla ochrony życia lub zdrowia ludzkiego. Wyłączona zostaje w ten sposób konieczność pracy w godzinach nadliczbowych w celu ochrony mienia lub środowiska albo usunięcia awarii. W takiej sytuacji dobro poświęcane przez pracowników w postaci ich zdrowia narażonego na działanie czynników szkodliwych jest dobrem większej wartości niż potrzeba ochrony mienia. Nie ma jednak podstaw do takiego różnicowania w oparciu o art. $151 \S 2$ k.p. Z tego względu pracodawca ma możliwość zlecić pracownikom zatrudnionym na tych stanowiskach pracę $\mathrm{w}$ godzinach nadliczbowych w sytuacjach awaryjnych ${ }^{32}$. Wykaz czynników szkodliwych dla zdrowia znajduje się w rozporządzeniu Ministra Pracy i Polityki Społecznej z dnia 23 czerwca 2014 r. w sprawie najwyższych dopuszczalnych stężeń i natężeń czynników szkodliwych dla zdrowia w środowisku pracy ${ }^{33}$.

\subsection{Pracownicy, którzy przedłożyli zaświadczenie o potrzebie czasowego wstrzymania się od pracy w godzinach nadliczbowych}

Z treści art. 207 k.p. należy wnioskować, że zakaz pracy w godzinach nadliczbowych stosuje się również do pracowników, którzy przedłożyli zaświadczenie właściwego zakładu opieki zdrowotnej o potrzebie czasowego wstrzymania się od pracy w godzinach nadliczbowych. Przepis ten stanowi, iż pracodawca obowiązany jest do ochrony zdrowia i życia pracowników poprzez zapewnienie bezpiecznych i higienicznych warunków pracy przy odpowiednim wykorzystaniu osiągnięć nauki i techniki. Na tej podstawie należy zwrócić uwagę na fakt, że

\footnotetext{
${ }^{32}$ B. Bury, Praca..., s. 95.

${ }^{33}$ Dz.U. z 2014 r. poz. 817.
} 
przepisy kodeksu pracy chronią przede wszystkim zdrowie pracownika, które ma pierwszeństwo przed interesem pracodawcy ${ }^{34}$.

\section{Względny zakaz zatrudniania w godzinach nadliczbowych}

Zgodnie z treścią art. $178 \S 2$ k.p. względny zakaz zatrudniania w godzinach nadliczbowych dotyczy pracowników opiekujących się dzieckiem do ukończenia przez nie 4. roku życia. Oznacza to, iż pracodawca, bez zgody pracownika, nie może zatrudnić go w godzinach nadliczbowych, a także nie może on narzucać pracy wbrew woli pracownika ${ }^{35}$. Regulacja ujęta $\mathrm{w}$ kodeksie pracy związana jest $\mathrm{z}$ trudnościami, jakie pojawiają się $\mathrm{w}$ kwestii pogodzenia obowiązków zawodowych $\mathrm{z}$ wychowywaniem dziecka. W ten sposób pracownikowi została przyznana ochrona przed obciążaniem go dodatkowymi obowiązkami. W tym przypadku zakaz zatrudniania pracownika w godzinach nadliczbowych ma charakter względny. Skutkuje to ograniczeniem kompetencji kierowniczych pracodawcy w tym zakresie. Pracownik ma prawo decydować o tym, czy takie rozwiązanie uznaje za korzystne dla siebie i swojej rodziny. Jego zgoda powinna być uprzednia, a także wyrażana każdorazowo przy propozycji pracy w godzinach nadliczbowych. Jeśli pracownik odmówi świadczenia pracy w godzinach nadliczbowych, to decyzja ta nie może pociągać za sobą ujemnych konsekwencji dla niego. Żaden przepis prawa nie stanowi o formie zgody, przypuszczalnie może ona zostać wyrażona również w sposób dorozumiany, poprzez czynności konkludentne. Dla celów ewidencyjnych, a także ze względu na walor ochrony przysługującej tej grupie pracowników wskazana jest jednak forma pisemna.

Sprawowanie opieki oznacza nie tylko posiadanie dziecka, ale również pozostawanie wraz z nim we wspólnym gospodarstwie domowym. Opieka ulega przerwaniu w przypadku czasowego oddania dziecka na wychowanie innej osobie lub rezygnacji z jego wychowania. Skutkuje to wygaśnięciem ochrony przewidzianej w art. $178 \S 2$ k.p ${ }^{36}$. Zgodnie z treścią art. $189^{1}$ k.p. jeżeli oboje rodzice lub opiekunowie dziecka są zatrudnieni, ze wskazanego wyżej uprawnienia może skorzystać tylko jedno z nich. Regulacje zawarte w art. 178 §2 k.p. dotyczą zarówno rodziców naturalnych, jak i przysposabiających, a ponadto osób, które przyjmują dzieci w ramach prawnej lub faktycznej pomocy rodziny zastępczej ${ }^{37}$

\footnotetext{
${ }^{34}$ Tamże, s. 96.

${ }^{35}$ M. Nałęcz, w: Kodeks..., s. 637.

${ }^{36}$ B. Bury, Praca..., s. 97.

${ }^{37}$ M. Nałęcz, w: Kodeks..., s. 637.
} 


\section{Uwagi końcowe}

Wskazuje się, że pracodawca przy zlecaniu pracy w godzinach nadliczbowych powinien kierować się nie tylko zakazami przewidzianymi w przepisach kodeksowych, lecz także zasadami współżycia społecznego. Pracodawcę obliguje do tego art. 8 k.p. Przykładem zlecenia pracy $\mathrm{w}$ godzinach nadliczbowych wbrew zasadom współżycia społecznego jest sytuacja, w której pracodawca wydaje pracownikowi polecenie takiej pracy, gdy nie może on wykonywać pracy w godzinach nadliczbowych ze względu na zły stan zdrowia, ważne obowiązki rodzinne, czy odległe dojazdy do pracy. W takich przypadkach ciężar udowodnienia, że polecenie pracy w godzinach nadliczbowych narusza zasady współżycia społecznego spoczywa na pracowniku.

Należy podkreślić, iż praca wykonywana ponad ustalone normy czasu pracy wymaga zwiększonego wysiłku ze strony pracownika, a także ogranicza jego czas wolny. $Z$ tego względu ustawodawca zdecydował się na wzmożoną ochronę niektórych pracowników. Zakazy pracy w godzinach nadliczbowych mają na celu ochronę pracowników przed ich nadmiernym wysiłkiem.

Pracodawca, który zleci pracownikowi pracę w godzinach nadliczbowych wbrew wskazanym powyżej zakazom, działa w sposób nielegalny, pracownik natomiast ma prawo odmówić wykonania takiej pracy ${ }^{38}$.

\section{Bibliografia:}

\section{Literatura}

Bury B., Praca w godzinach nadliczbowych, Warszawa 2007

Chobot A., Czas pracy w znowelizowanym kodeksie pracy, Poznań 1998

Florek L., Prawo pracy, Warszawa 2012

Jaroszewska - Ignatowska I., Czas pracy po nowelizacji, Warszawa 2003

Muszalski W. (red.), Kodeks pracy. Komentarz, Warszawa 2005

Thiel A., Czas pracy osób niepetnosprawnych, w: Zatrudnianie osób niepetnosprawnych. Regulacje prawne, red. A. Giedrewicz - Niewińska, M. Szabłowska - Juckiewicz, Warszawa 2014

Wąż P., Polecenie pracy $w$ godzinach nadliczbowych, http://www.pracaizdrowie.com.pl/content/view/480/3/

Wronikowska W., Wynagrodzenie za pracę w godzinach nadliczbowych, Warszawa 2007

\section{Orzecznictwo}

Wyrok Sądu Najwyższego z dnia 16 grudnia 1987 r., I PRN 68/87, OSNCP, z. 10, poz. 164

Wyrok Sądu Najwyższego z dnia 26 maja 2000 r., I PKN 667/99, OSN 2001, nr 22, poz. 662

Wyrok Sądu Najwyższego z dnia 10 marca 2005 r., II PK 241/04, OSNP, nr 24, poz. 393

\footnotetext{
${ }^{38}$ E. Wronikowska, Wynagrodzenie..., s. 51-52.
} 